\title{
Relationship between Entrepreneurial Orientation, Firm Resources, SME Branding and Firm's Performance: Is Innovation the Missing Link?
}

\author{
Muhammad Haroon Hafeez, Mohd Noor Mohd Shariff, Halim Bin Mad Lazim
}

College of Business, Universiti Utara Malaysia, Sintok, Malaysia.

Email: s93694@student.uum.edu.my,mdnoor@uum.edu.my,mlhalim@uum.edu.my

Received July $1^{\text {st }}$, 2012; revised July 30 ${ }^{\text {th }}$, 2012; accepted August 29 ${ }^{\text {th }}, 2012$

\begin{abstract}
Innovation is regarded as an engine for driving economic growth. Innovation is considered equally important for the large enterprises as well as the Small and Medium Enterprises (SMEs). Role of innovation becomes of even greater importance in the context of the business environment of developing countries such as Pakistan, where most of the SMEs do not embrace rigorous innovation and at the same time there is lack of sufficient external support to encourage innovation. It has been discussed that despite of healthy economic contribution to Pakistan's Economy, SMEs are facing a low growth trap. Innovation can come up as a potential solution specifically for Pakistani SMEs and generally for SMEs in developing countries in other parts of the world. This paper reviews the literature in a thorough manner in a bid to build a novel conceptual framework proposing that innovation has causal linkages with entrepreneurial orientation, firm resources, branding and firm performance. On the basis of literature review, four thoughtful research propositions have been presented in this paper. The proposed framework can lead to very useful insights as it proposes that branding may lead to innovation as opposed to generally believed concept of innovation leading to branding. This paper is built on the underpinning theories like Resource Based View, Dynamic Capabilities Perspective, and Theory of Economic Development. This paper also provides useful implications for the entrepreneurs as well as external institutions responsible for ensuring higher extent of innovation in SMEs in Pakistan.
\end{abstract}

Keywords: Entrepreneurial Orientation; Firm Resources; SME Branding; Innovation; SMEs in Pakistan

\section{Introduction}

SMEs are considered as the spine of Pakistan Economy as they are playing a significant role in generating employment opportunities, poverty reduction and thus contributing towards creation of better standards of living. SMEs represent more than 95 percent of Pakistani business enterprises and therefore account for employment of nearly 80 percent of non-agricultural/industrial labor force in Pakistan. According to [1] SMEs contributed 30 percent of gross domestic product (GDP) in 2010-2011. The critical importance of SMEs can be further emphasized by the fact that the real GDP of Pakistan rose only by 2.4 percent in 2010-2011, SMEs delivered much needed assistance. Small and Medium Enterprises Development Authority (SMEDA) approved 28 new SME projects worth Rs. 2.8 billion in 2010-2011. Thus, it is appropriate to argue that SMEs can significantly sustain and increase business performance even in the times of economic instability and turbulence. The term "SME" was coined by the European Commission for the firms employing lesser than 250 employees [2].

SMEs have been defined by various institutions in Pakistan in a different manner as shown in Table $\mathbf{1 .}$

Reference [3] argued that although SMEs are driving the economy of Pakistan if viewed from a cumulative perspective, yet a more analytical insight reveals that a large number of Pakistani SMEs are experiencing dismal growth and are battling for survival of their businesses. This argument is authenticated from the factual evidences that less than 20 percent of SMEs are operating for lesser than four years and less than 05 percent of SMEs are doing business for more than 25 years.

This scenario is worth investigating in order to come up with potential vision to avoid rapid failures and business shutdowns. A look at Table 2 shows that the performance of small scale manufacturing firms in recent decade was quite dismal compared to previous decades.

There is no shortage of entrepreneurial intent and desire to succeed, financial problems can be sought out by SME bank and other micro finance banks, human talent 
Table 1. SMEs definitions by various institutions in Pakistan.

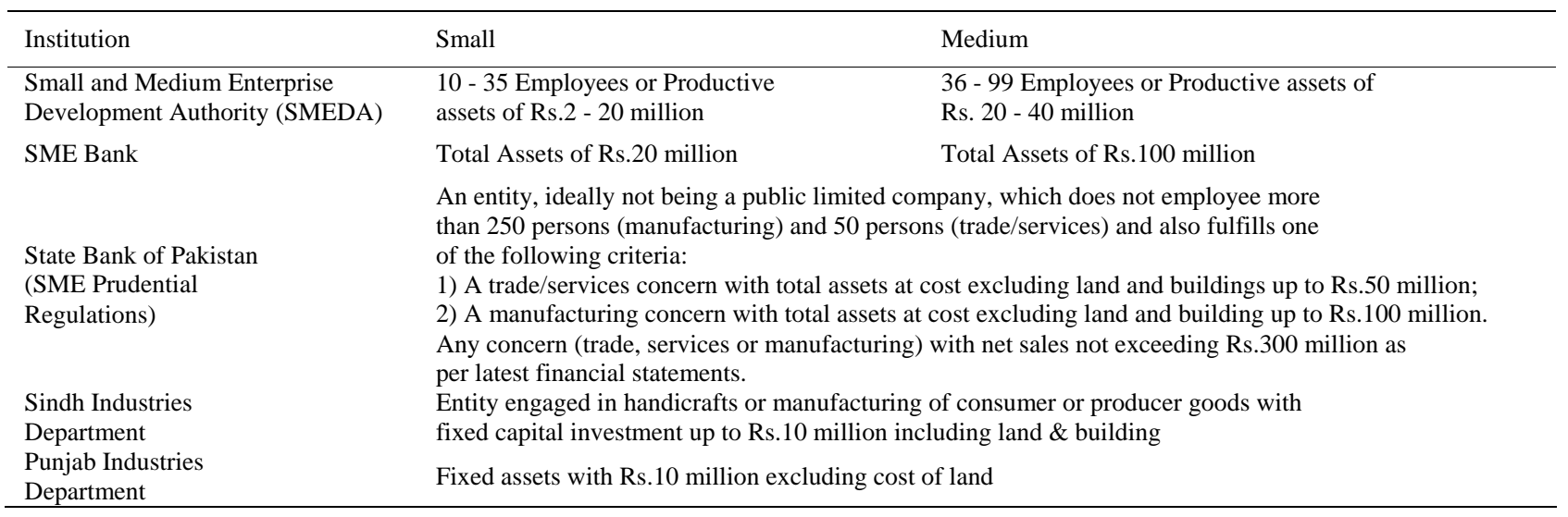

Source: Small and Medium Enterprises Development Authority (SMEDA).

Table 2. Growth performance of small scale manufacturing in Pakistan: A decade-wise comparison.

\begin{tabular}{cc}
\hline Years & Growth Performance of SME Manufacturing in Pakistan \\
\hline $1981-1990$ & $8.4 \%$ \\
$1991-2000$ & $7.8 \%$ \\
$2001-2010$ & $4.6 \%$ \\
\hline
\end{tabular}

Source: Ministry of Finance, 2011.

is available, networking alliances are there in the clusters such as Fan Manufacturing (Gujranwala), Cutlery (Wazirabad), Blue Pottery (Multan), Furniture (Chiniot), Sports \& Surgical (Sialkot). SME branding though, is in its inception, yet it is evident in case of industries such as fan manufacturing and in case of few sports and surgical firms. In this regard the big question to ponder is that what the missing link is. The answer probably lies in adoption of innovation, as most of the above mentioned clusters are labor intensive and thus rely on less efficient technologies and older ways of executing administrative and marketing tasks. With regards to innovation both technical and non technical dimensions of innovation are important. Bringing technological innovation is not enough, innovation regarding introducing new products (product innovation), managing the employees and carrying the everyday tasks (managerial or administrative innovation), looking for new customers, seeking new ways to position and promote the products and services (Market and Marketing innovations) are also equally important for superior performance in SMEs [4].

In the recent Economic Survey of Pakistan [5] the emphasis is on enhancing the orientation and intensity of innovation in order to achieve higher firm performance and growth. Reference [6] identified lack of initiative and capability to embrace new technology as substantial causes that hamper the growth performance of SMEs in
Pakistan. Reference [7] described deficiency of firms' ability and government assistance for innovation as causes of poor business performance. SMEs cannot afford to bear all costs of technology adoption and innovation by themselves. In this regard they require active support from the government. Role of technology parks and incubation centers is crucial for technology adoption and innovation. In this regard, Finland can be quoted as a success story. It has more than 18 technology incubators located in various science parks in different parts of the country. According to [8] Finland has been ranked among 03 most innovative countries with an innovation performance score of 9.50. In Pakistan, there are only 03 well established technology parks/incubation centers. Although Ministry of Science and Technology (MoST) in collaboration with SMEDA and other research institutes, is undertaking positive steps to develop and promote technology parks, the substantial outcomes are yet to be witnessed as Pakistan lies almost at the bottom of the list of most innovative countries. Pakistan with an innovation performance index score of 3.13 has been ranked $77^{\text {th }}$ among 82 countries [8].

\section{Conceptual Framework and Literature Review}

The theoretical base of this paper is founded by reviewing the literature. In the literature, causal linkages have been identified among entrepreneurial orientation, firm resources, SME branding, innovation and firm performance. Figure 1 elaborates all the linkages in a sequential manner.

This figure shows that Innovation is an outcome variable of Entrepreneurial Orientation, Firm Resources and SME Branding. Subsequently Innovation leads towards Firm performance. The rationale for the linkages shown in the Figure 1 is grounded in the literature as discussed in the following part. 


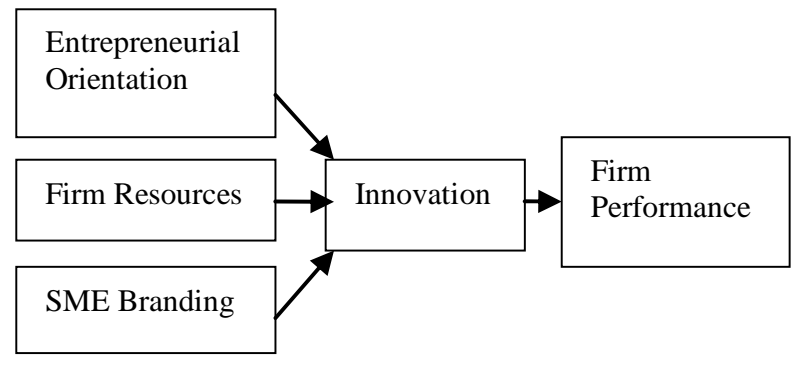

Figure 1. Conceptual framework.

\subsection{Linkage between Entrepreneurial Orientation and Innovation}

Entrepreneurial Orientation can inhibit or foster Innovation process. Several studies have stressed upon the ties between entrepreneurial orientation and innovation [914]. Reference [15] argues that entrepreneurship in itself is a pragmatic manner leading towards innovation and new venture establishment by assuming higher risks and rewards associated with the new venture. According to $[16,17]$ entrepreneurial orientation refers to the tendency of a firm to indulge in innovative, proactive and risk prone ventures. In the light of literature it can be argued with confidence that innovation is a function of entrepreneurial orientation. Similarly the literature asserts a significant relationship between Entrepreneurial Orientation and firm performance [18]. Entrepreneurial Orientation is considered as a behavioral procedure that operates at firm level. If entrepreneurial orientation is prone towards innovation, there is a greater likelihood that the firm would embrace and manage innovation in more effective manner as compared to those firms where entrepreneurs are less innovative and risk aversive; resultantly perform better than the competitors.

\subsection{Linkage between Firm Resources and Innovation}

Innovation cannot be achieved in isolation. Researchers have thoroughly investigated the interaction among firm resources and the extent to which it can manage innovation. Resource based view (RBV) is a significant and most cited theoretical foundation in this context. While elaborating resource based view, [19] emphasizes the significance and role of firm's unique resources and distinct competencies in determining the magnitude of firm's capacity to manage innovation. Reference [20] extended resource based view by formulating dynamic capabilities perspective which gives importance to those organizational processes which employ organizational resources. Thus, dynamic capabilities perspective states that what really matters is how efficiently and effectively the critical resources are employed by the various proc- esses taking place at different levels within the firm. Reference [21] regards critical resources as highly instrumental in gaining differential advantage and higher firm performance. Critical resources may refer to financial resources, human resources and networking alliances [18]. SMEs that are financially constrained face difficulties in pursing innovation. Whereas, those SMEs which enjoy sound financial health can afford experimentation and follow innovative procedures more rigorously [22, 23]. Reference [24] signifies the importance of human capital for products and process improvements leading ultimately towards higher performance. There are numerous studies that have stressed on the contribution of human capital towards venture creation, survival, development and growth of firms [25-27]. Reference [26] has also highlighted the prominence of networking resources in knowledge sharing and technology transfers that enable the firms towards innovative products and processes.

\subsection{Linkage between SME Branding and Innovation}

Branding is generally believed as a business of large corporate firms. Because of their resources and economic power, they have been considered as more suited to the phenomenon of branding. Thus, branding in SMEs have been largely neglected by marketing and branding gurus such as Philip Kotler, David Aaker, Kevin lane Keller and Jean Noel Kapferer. Their footsteps were followed by fellow researchers in the field of brand management. Hence, the conceptualization of Branding in SMEs could not nourish till the start of new millennium.

Branding in SMEs became the subject of academic interest since the beginning of past decade when [28] coined the term "SME Branding". There exist only a few noteworthy researches in this area [28-33]. The significance of branding in the perspective of SMEs is multifarious. Branding can assist SMEs in building corporate image [34], achieving superior performance [35], pursuit of innovative process and eventually reaping competitive advantage [36]. According to [37] branding creates the room for rigorous technological up gradation and innovation. Furthermore, the focus on brands and branding activities accelerates the pace of introduction of innovative products that are highly competitive and hard to imitate thus enables the firm to achieve long lasting growth [28]. Hence, branding activities can have a multiplier effect on SMEs' innovation led firm performance.

\subsection{Linkage between Innovation and Firm Performance}

Innovation refers to the ability of a firm to commercialize 
its invention [38]. The linkage between innovation and firm performance is quite evident from the past and current literature [39-42]. Innovation is regarded as a crucial element for business growth and a critical factor for attaining long serving differential advantage [43,44]. Researchers have clearly argued in favor of innovation for higher firm performance by stating that disregarding innovation can lead to business demise [37,45]. In the context of SMEs innovation refers to seeking novel ways of doing business, looking for introduction of differentiated products in order to grasp the marketing and economic benefits such as higher profits, market share and sustainable competitive advantage [46]. In the perspective of SMEs, [4] identified five types of innovations (Product or Service, Market development, Marketing, Process technology and Administrative innovations). According to [47] innovation can be internal, cooperative or external as far as its mode is concerned. Internal innovation refers to firm's self-reliance on its sources and competencies. Cooperative innovation means that the firm employs its own as well as its networks' resources and competencies. External innovation indicates that the firm is not capable of organic innovation and it depends upon innovation supported by external environment that may include the assistance from government agencies and firms' supply chain partners. Furthermore, it has been found in the literature that firms that are more prone to innovation perform higher as compared to those who resist innovation [48-50]. In the light of above mentioned studies it is appropriate to say that in this fast paced age of globalization and hyper competition, innovation is the way forward for the entrepreneurs who want their businesses not only to survive but also to exhibit sustained growth.

\section{Research Methodology}

In this paper a conceptual framework has been proposed whereby innovation mediates the linkage between Entrepreneurial Orientation, Firm Resources, SME Branding and Firm Performance. The methodology adopted for this paper is conceptual modeling to present a novel framework which can combine the significant predictors of firm performance in SMEs. To build this conceptual model we have analyzed several secondary data sources in detail. A thorough literature review of more than 100 conceptual and Research papers written by prominent researchers in the field of Entrepreneurship, Innovation and Brand Management has been conducted. Special emphasis has been given to studies conducted in the context of SMEs. Literature review takes in to account the scholarly sources from 1934 to 2012. In addition to scholarly articles, other data sources employed in this study include: Highly cited Books, Conference Proceed- ings and working papers in the field of Entrepreneurial Branding and Innovation Research. These sources have been reviewed to have a comprehensive insight of any potential gaps in the previous studies. Furthermore, Publications by Small and Medium Enterprise Development Authority of Pakistan (SMEDA), Publications of Ministry of Finance (MOF), Government of Pakistan, News Articles from credible sources have been reviewed to study the current state of growth performance, firms' resourcefulness, innovation and branding practices in SMEs in Pakistan. Moreover, information from official websites of various national and international research agencies and institutes have been reviewed to present the interesting findings with reference to issues discussed in the paper.

On the basis of aforementioned literature review, a new conceptual framework/model has been proposed which proposes the following Research Propositions (RPs).

$\mathrm{RP}_{1}$ : Innovation mediates the relationship between Entrepreneurial Orientation and Firm Performance;

$\mathrm{RP}_{2}$ : Innovation mediates the relationship between Firm Resources and Firm Performance;

$\mathrm{RP}_{3}$ : Innovation mediates the relationship between SME Branding and Firm Performance;

$\mathrm{RP}_{4}$ : Innovation mediates the relationship between Entrepreneurial Orientation, Firm Resources, SME Branding and Firm Performance.

\section{Discussion, Conclusion and Implications}

This paper attempts to describe the catalytic role of innovation in improving firm performance in SMEs in Pakistan. As discussed in the introductory section of the paper, the performance of SMEs in last Pakistan in last decade has been quite dismal. In comparison with (1981-2000), the performance has declined and stagnated. So there is a dire need to come up with dynamic measures. Innovation can be one of those dynamic measures that can spark growth and enable firms to break the status quo and leapfrog towards superior performance. Thus, the paper sheds light on the significance of innovation in SMEs by reviewing the past and recent relevant literature that discusses the linkage between innovation and firm performance. It also proposes a theoretical framework where innovation mediates the relationship between entrepreneurial orientation, firm resources, SME Branding and firm performance. Innovation is quite a daunting task as it depends on certain pre-requisite conditions. Small and medium firms' propensity and ability to innovate depends upon the entrepreneurs' orientation towards risk taking and innovativeness. Entrepreneurs are largely responsible for shaping the culture of their firms by the positive orientation towards innovation that may enable 
them to identify and avail the attractive market opportunities [51]. It also rests largely upon firms' critical resources as discussed in resource based view (RBV) [19,52]. Moreover firms' orientation towards branding can lead the firms towards rigorous innovation in a bid to retain the existing and attract the new customers, thus expanding the overall customer base, increasing the market share and achieving high growth performance. It can be considered as the major contribution of the proposed framework because it contradicts with the well established view presented by $[53,54]$ who asserted that innovation serves as a platform for launching branding activities. The framework supports the view proposed by [28] that preexistence of branding practices can also serve as a launching pad for aggressive pursuit of innovation. It would be very interesting to empirically test this proposition. If proven, this proposition would lead the firms in pursuit of Brand led innovation excellence strategy. Thus, the emphasis on branding processes in SMEs would increase, which would serve not only the SMEs but also the society at large. This new strategy would ultimately contribute towards the economic growth of the countries depending largely on the performance of their SMEs.

In Pakistan, the establishment of SMEDA proved to be a landmark for the promotion of SMEs. Subsequently SME bank was established to help small and medium firms regarding financing problems. SMEDA was instrumental in developing a comprehensive SME policy in 2006-2007 [55]. As far as usefulness of policy is concerned, there is no denial, but it is yet to be implemented as documented. In order to meet the financing needs of entrepreneurs there is a dire need of more micro finance banks and venture capital firms. To promote innovation, government must provide required socio-technological support to the entrepreneurs so that they can take innovative measures with more confidence. More technology parks, business incubation centers and advisory cells must be established in future in this regard. Furthermore entrepreneurs also need to lessen the emphasis on traditional and older ways of operating businesses; reliance on existing and commodity type products should also be minimized. They should embrace new technologies to improve their existing business processes and should invest in branding activities to foster product innovation [28], in addition innovation practices should also be embraced in managerial and marketing activities [4] in order to achieve highly sustainable competitive advantage and superior firm performance.

\section{Future Research}

This paper proposes a significant framework which can be empirically tested in different countries especially the developing countries; and across different industries in order to generalize the findings. It would be very interesting to study the differences in entrepreneurial orientations, critical firm resources, branding strategies and innovation practices among SMEs and to analyze their impact on firms' performance. Furthermore, longitudinal studies in this regard can make invaluable contribution in the academic literature regarding brand management and innovation practices in SMEs. Future researchers can also look for exploring the empirical relationship between Branding and Innovation in SMEs; therefore the framework in this paper tries to lead the researchers towards a new path for re-examining this important linkage and possibly building a new theory.

\section{REFERENCES}

[1] Ministry of Finance, "Pakistan Economic Survey 20102011,” Government of Pakistan, Ministry of Finance, Islamabad, 2011.

[2] P. Burns, "Entrepreneurship and Small Business," Palgrave MacMillan, Basingstoke, 2001.

[3] S. Khawaja, "Unleashing the Potential of the SME Sector with a Focus on Productivity Improvements,” 2006. http://siteresources.worldbank.org/PAKISTANEXTN/Re sources/293051-1147261112833/Session-3-2.pdf

[4] D. North and D. Smallbone, "The Innovativeness and Growth of Rural SMEs during the 1990s," Regional Studies, Vol. 34, No. 2, 2000, pp. 145-157. doi:10.1080/00343400050006069

[5] Ministry of Finance, "Pakistan Economic Survey 20112012,” Government of Pakistan, Islamabad, 2012.

[6] S. Z. Hassan, W. M. Khan and K. A. Saeed, "Technology Choice by SMEs in Pakistan,” Konrad Adenauer Foundation Working Paper Series, LUMS, Lahore, 1998.

[7] I. Hussain, S. Si, X. M. Xie and L. Wang, "Comparative Study on Impact of Internal and External CFFs on SMEs," Journal of Small Business and Entrepreneurship, Vol. 23, No. 4, 2010, pp. 637-648.

[8] Economist Intelligence Unit, “A New Ranking of the World's Most Innovative Countries an Economist Intelligence Unit Report,” 2009. http://graphics.eiu.com/PDF/Cisco_Innovation_Complete.pdf

[9] D. Miller, "The Correlates of Entrepreneurship in Three Types of Firms,” Management Science, Vol. 29, No. 7, 1983, pp. 770-791. doi:10.1287/mnsc.29.7.770

[10] J. G. Covin and D. P. Slevin, "Strategic Management of Small Firms in Hostile and Benign Environments," Strategic Management Journal, Vol. 10, No. 11, 1989, pp. 7587. doi:10.1002/smj.4250100107

[11] D. S. Schafer, "Level of Entrepreneurship as Scanning Source Usage in very Small Businesses," Entrepreneurship Theory and Practice, Vol. 15, No. 2, 1990, pp. 9-31.

[12] B. R. Barringer and A. C. Bluedorn, "The Relationship 
between Corporate Entrepreneurship and Strategic Management,” Strategic Management Journal, Vol. 13, 1999, pp. 363-380.

[13] J. Wicklund and D. Shepherd, "Knowledge-Based Resources, Entrepreneurial Orientation, and the Performance of Small and Medium-Sized Businesses," Strategic Management Journal, Vol. 24, No. 13, 2003, pp. 1307-1314. doi:10.1002/smj.360

[14] R. Harms, A. Schulz, S. Kraus and M. Fink, “The Conceptualization of 'Opportunity' in Strategic Management Research,” International Journal of Entrepreneurial Venturing, Vol. 1, No. 1, 2009, pp. 57-71. doi:10.1504/IJEV.2009.023820

[15] R. D. Hisrich and M. P. Peters, "Entrepreneurship: Starting, Developing and Managing a New Enterprise,” Homewood IL, Irwin, 1989.

[16] G. T. Lumpkin and G. G. Dess, "Clarifying the Entrepreneurial Orientation Construct and Linking It to Performance," Academy of Management Review, Vol. 21, No. 1, 1996, pp. 135-172.

[17] G. T. Lumpkin and G. G. Dess, "Linking Two Dimensions of Entrepreneurial Orientation to Firm Performance: The Moderating Role of Environment and Industry Life Cycle,” Journal of Business Venturing, Vol. 16, No. 5, 2001, pp. 429-451. doi:10.1016/S0883-9026(00)00048-3

[18] J. Wicklund, H. Patzelt and D. Shepherd, "Building an Integrated Model of Small Business Growth,” Small Business Economics, Vol. 32, No. 4, 2009, pp. 351-374. doi:10.1007/s11187-007-9084-8

[19] J. B. Barney, "Strategic Factor Markets: Expectations, Luck, and Business Strategy," Management Science, Vol. 32, No. 10, 1986, pp. 1231-1241. doi:10.1287/mnsc.32.10.1231

[20] D. J. Teece, G. Pisano and A. Shuen, "Dynamic Capabilities and Strategic Management," Strategic Management Journal, Vol. 18, No. 7, 1997, pp. 509-533. doi:10.1002/(SICI)1097-0266(199708)18:7<509::AID-S MJ882>3.0.CO;2-Z

[21] B. Wernerfelt, "A Resource-Based View of the Firm,” Strategic Management Journal, Vol. 5, No. 2, 1984, pp. 171180. doi:10.1002/smj.4250050207

[22] G. J. Castrogiovianni, "Pre-Start-Up Planning and the Survival of New Small Firms," Journal of Management, Vol. 22, No. 6, 1996, pp. 801-823. doi:10.1177/014920639602200601

[23] S. Zahra, "Predictors and Financial Outcomes of Corporate Entrepreneurship: An Explorative Study,” Journal of Business Venturing, Vol. 6, No. 6, 1991, pp. 259-285. doi:10.1016/0883-9026(91)90019-A

[24] D. C. Galunic and E. Anderson, "From Security to Mobility: Generalized Investments in Human Capital and Agent Commitment,” Organization Science Linthicum, Vol. 11, No. 1, 2000, pp. 1-20. doi:10.1287/orsc.11.1.1.12565

[25] D. Hoxha, "The Performance of Micro Firms in Kosova: Size, Age and Educational Implications,” International Journal of Globalization and Small Business, Vol. 3, No.
1, 2009, pp. 25-40. doi:10.1504/IJGSB.2009.021568

[26] D. Brown, S. Earle and D. Lup, "What Makes Small Firms Grow? Finance, Human Capital, Technical Assistance, and the Business Environment in Romania," Economic Development and Cultural Change, Vol. 54, No. 1, 2005, pp. 33-70. doi:10.1086/431264

[27] G. N. Chandler and S. H. Hanks, "Market Attractiveness, Resource-Based Capabilities, Venture Strategies and Venture Performance,” Journal of Small Business Management, Vol. 12, No. 1, 1994, pp. 27-35.

[28] T. Abimbola, "Branding as a Competitive Strategy for Demand Management in SMEs,” Journal of Research in Marketing \& Entrepreneurship, Vol. 3, No. 2, 2001, pp. 97-106.

[29] I. Inskip, "Corporate Branding for Small to MediumSized Businesses-A Missed Opportunity or an Indulgence?” Journal of Brand Management, Vol. 11, No. 4, 2004, pp. 358-365. doi:10.1057/palgrave.bm.2540181

[30] F. Krake, "Successful Brand Management in SMEs: A New Theory and Practical Hints," Journal of Product \& Brand Management, Vol. 14, No. 4-5, 2005, pp. 228-239. doi:10.1108/10610420510609230

[31] H. Y. Wong and B. Merrilees, "A Brand Orientation Typology for SMEs: A Case Research Approach,” Journal of Product \& Brand Management, Vol. 14, No. 2-3, 2005, pp. 155-162. doi:10.1108/10610420510601021

[32] T. Abimbola and C. Vallaster, "Brand, Organizational Identity and Reputation in SMEs: An Overview,” Qualitative Market Research: An International Journal, Vol. 10, No. 4, 2007, pp. 341-348. doi:10.1108/13522750710819685

[33] J. Ojasalo, S. Natti and R. Olkkonen, "Brand Building in Software SMEs: An Empirical Study," Journal of Product \& Brand Management, Vol. 17, No. 2, 2008, pp. 92107. doi:10.1108/10610420810864702

[34] V. Rode and C. Vallaster, "Corporate Branding for StartUps: The Crucial Role of Entrepreneurs,” Corporate Reputation Review, Vol. 8, No. 2, 2005, pp. 121-137. http://doi:10.1057/palgrave.crr.1540244

[35] P. Berthon, M. T. Ewing and J. Napoli, "Brand Management in Small to Medium-Sized Enterprises," Journal of Small Business Management, Vol. 46, No. 1, 2008, pp. 27-45. doi:10.1111/j.1540-627X.2007.00229.x

[36] E. T. Penrose, "Theory of the Growth of the Firm," 3rd Edition, Basil Blackwell, Oxford, 1995. doi:10.1093/0198289774.001.0001

[37] G. Hamel and C. K. Prahalad, "Competing for the Future,” Harvard Business School Press, Boston, 1994.

[38] M. A. Hitt, R. D. Ireland and R. E. Hoskisson, "Strategic Management: Competitiveness and Globalization,” 5th Edition, International Thomson Publishing, Cincinnati, 2001.

[39] R. J. Calantone, S. T. Cavusgil and Y. Zhao, "Learning Orientation, Firm Innovation Capability, and Firm Performance,” Industrial Marketing Management, Vol. 31, No. 6, 2002, pp. 515-524. doi:10.1016/S0019-8501(01)00203-6 
[40] L. Klomp and G. van Leeuwen, "Linking Innovation and Firm Performance: A New Approach,” International Journal of the Economics of Business, Vol. 8, No. 3, 2001, pp. 343-364. doi:10.1080/13571510110079612

[41] T. Li and R. J. Calantone, "The Impact of Market Knowledge Competence on New Product Advantage: Conceptualization and Empirical Examination,” Journal of Marketing, Vol. 62, No. 4, 1998, pp. 13-29. doi:10.2307/1252284

[42] M. A. Mone, W. McKinley and V. L. Barker, “Organizational Decline and Innovation: A Contingency Framework," Academy of Management Review, Vol. 23, No. 1, 1998, pp. 115-132.

[43] G. G. Dess and J. C. Picken, "Changing Roles: Leadership in the 21st Century,” Organizational Dynamics, Vol. 28, No. 3, 2000, pp. 18-34. doi:10.1016/S0090-2616(00)88447-8

[44] M. Marchese, "Issues Paper," International Conference on SMEs, Entrepreneurship and Innovation, OECD LEED Programme, Udine, 22-23 October 2009.

[45] G. Hamel, "Leading the Revolution," Harvard Business School Press, Boston, 2000.

[46] J. A. Schumpeter, “Theory of Economic Development,” Harvard University Press, Cambridge, 1934.

[47] R. E. Hoskisson and L. W. Busenitz, "Market Uncertainty and Learning Distance in Corporate Entrepreneurship Entry Mode Choice, in Creating a New Mindset: Integrating Strategy and Entrepreneurship Perspectives,” Blackwell Publishing, Oxford, 2002.
[48] S. Thornhill, "Knowledge, Innovation and Firm Performance in High and Low Technology Regimes," Journal of Business Venturing, Vol. 21, No. 5, 2006, pp. 687703. doi:10.1016/j.jbusvent.2005.06.001

[49] M. A. Mansury and J. H. Love, "Innovation, Productivity and Growth in US Business Services: A Firm-Level Analysis," Technovation, Vol. 28, No. 1-2, 2008, pp. 5262. doi:10.1016/j.technovation.2007.06.002

[50] D. Jimenez-Jimenez and R. Sanz-Valle, "Innovation, Organizational Learning and Performance," Journal of Business Research, Vol. 64, No. 4, 2011, pp. 408-417. doi:10.1016/j.jbusres.2010.09.010

[51] D. Stokes, "Putting Entrepreneurship into Marketing," Journal of Research in Marketing and Entrepreneurship, Vol. 2, No. 1, 2000, pp. 1-16. doi:10.1108/14715200080001536

[52] J. B. Barney, "Firm Resources and Sustained Competitive Advantage,” Journal of Management, Vol. 17, No. 1, 1991, pp. 99-120. doi:10.1177/014920639101700108

[53] J. N. Kapferer, "Strategic Brand Management: Creating and Sustaining Brand Equity Long Term,” 2nd Edition, Kogan Page, Great Britain, 1997.

[54] K. L. Keller, "Strategic Brand Management: Building, Measuring and Managing Brand Equity,” Prentice Hall, Upper Saddle River, 1998.

[55] SMEDA, "Developing SME Policy in Pakistan, SME Issues Paper for Deliberation by SME Task Force,” 2006. http://www.smeda.org.pk/downloads/SME_Issues_Paper. pdf 